Up to the present, the basis of liability in control situations has been negligence or fraud. An attempt should be made to extend these concepts in order to bring about an equitable solution without the drastic and undesirable consequences of abolishing all profit which inheres in the control of a corporation and abandoning a basic tenet of free enterprise philosophy. ${ }^{9}$

\title{
INADEQUATELY CAPITALIZED SUBSIDIARIES
}

The ritual of incorporation provides a method of insulating assets from business risks. Yet the ritual affords no protection, to a parent corporation whose subsidiary" may be designated as its "alter ego" or its "instrumentality." Of the many factors considered by the courts in establishing that relationship, none is more elusive than inadequate capitalization. ${ }^{2}$

Cases in which the subsidiary was incorporated with substantially no assets of its own, or under its control, have been easy to decide. In Garden City Company v. Burden, ${ }^{3}$ a parent corporation which owned most of the water rights in

${ }^{9}$ The situation outlined in the Sun-Times articles could more accurately have been analyzed in terms of an abuse of a director-officer's relationship with other shareholders. If there was anything improper in what the president did it was done at the time he bought the shares from the other shareholders without revealing that he had an opportunity to dispose of control at a premium. (See note 2 supra.) The author's preoccupation with an abuse of the sale of control seems to have been mainly misdirected.

There are three rules in this situation, all of which are presented in American Trust Co. v. Calif. Western States Life Ins. Co., 15 Cal. 2d 42, 56, 98 P. 2d 497, 504 (1940). The minority rule, given support in Berle, Publicity of Accounts and Directors' Purchases of Stock, 25 Mich. L. Rev. 827 (1927), recognizes the "director's obligation to the stockholders individually as well as collectively, and refuses to permit him to profit at the latters' expense by the use of information obtained as a result of his official position and duties." The majority rule is that a "corporation director owes no fiduciary obligation to the stockholder as such, but only to the corporation. Hence... non-disclosure [is] not fraudulent because there [is] no duty to disclose." The special facts doctrine, as laid down in Strong v. Repide, 213 U.S. 419 (1909) is that "where special circumstances or facts are present which make it inequitable for the director to withhold information from the stockholder, the duty to disclose arises, and concealment is fraud."

${ }^{1}$ The attempted insulation is most common in the parent-subsidiary relationship although it may also be seen in the "one-man" corporation. Pepper v. Litton, 308 U.S. 295 (1939). There appears to be no reason why a distinction should be made between parent corporations as stockholders and the stockholder in the "one-man" corporation in the case of corporations organized with inadequate capital. However, liability appears to be more frequently limited when the stockholder is not a corporate entity. Consult Latty, Subsidiaries and Affiliated Corporations $194 \mathrm{ff}$. (1936).

2 Douglas and Shanks, Insulation From Liability Through Subsidiary Corporations, 39 Yale L.J. 193 (1929). The authors list eighteen relationships between parent and subsidiary saying of inadequate capital: "Courts are more impressed by an obvious inadequacy of capital on the part of the subsidiary than they are by the presence of any of the indicia of identity between the corporations. ... In fact, sufficient capital and adequate financial arrangements or the lack of it, insofar as the various factors motivating the courts are capable of ascertainment from the cases, in some instances seems to be largely determinative." Ibid., at 214.

${ }^{3} 186$ F. 2d 651 (C.A. 10th, 1951). The case follows almost directly the landmark case of Erickson v. Minnesota \& Ontario Power Co., 134 Minn. 209, 158 N.W. 979 (1916). 
a canal formed a subsidiary with an easement in the canal as its sole asset. In Joseph R. Foard Co. v. Maryland, ${ }^{4}$ a ship brokerage company formed a stevedoring company but held its assets, shared its officers, and retained all its profits. And in Wallace v. Tulsa Yellow Cab Taxi \& Baggage Co., ${ }^{5}$ the defendant, in order to procure public liability insurance, organized a corporation with a capital stock of $\$ 1,000$ purchased by the defendant's employees with money furnished by the defendant's president. The sole asset of the new corporation was an equipment lease from the defendant which could be cancelled on twenty-four hour notice. Revenue of the new corporation was completely absorbed by operating expenses and rental payments to the defendant. The parent corporations in these cases were held directly liable for claims against the subsidiaries.

The initial financial structure of the subsidiaries in these cases had two aspects in common. One was that the business could not be conducted independently of the parent corporations' control and financial support. The other was that regardless of the type of business involved, the nominal investment made it impossible to find even a minimal creditor cushion. A relationship between these two aspects was established by Luckenbach S.S. Co. v. W. R. Grace \& $\mathrm{Co}^{6}{ }^{6}$ A subsidiary was organized with a capital of $\$ 10,000$ to operate a fleet of ships leased from the parent. While the capital investment was more than nominal, it was nevertheless inadequate. The court reasoned that since "[f]or all practical purposes the two concerns are one, ... it would be unconscionable to allow the owner of this fleet of steamers, worth millions of dollars, to escape liability because it had turned them over a year before to a $\$ 10,000$ corporation, which is simply itself in another form." So the relationship appears to be that, whenever a subsidiary is the alter ego of its parent, the creditor cushion required of the subsidiary depends upon the degree of responsibility shifted to it.

Not infrequently, cases concerned with inadequate capitalization also involve the problem of determining the rights of the parent as a secured creditor of the subsidiary. These cases, like those previously discussed, may be grouped into two classifications: financial schemes with nominal capitalization at the outset, and schemes where the capital is more than nominal yet inadequate in terms of the risks involved in the subsidiary's business. Albert Richards Co. v. The May$\mathrm{fair}^{8}$ is an example of the first group. There a nominal amount was paid for capital stock while most of the original financing was in the form of loans by the

4219 Fed. 827 (C.A. 4th, 1914).

5178 Okla. 15, 61 P. 2d 645 (1936).

6267 Fed. 676 (C.A. 4th, 1920).

${ }^{7}$ Ibid., at 681.

8287 Mass. 280, 191 N.E. 430 (1934). Also where directors of a bank formed a corporation, paying for the entire stock of $\$ 5,000$ and conveying property to the corporation, while in turn the corporation executed to the bank its demand notes for $\$ 37,000$ plus a mortgage purporting to secure an issue of bonds, the bank was held liable for the sale of oil which was inferior in grade to what the contract specified. Here, although capital stock was issued, the primary source of funds was loaned and secured by mortgage. Portsmouth Cotton Oil Refining Corp. v. Fourth Nat'l Bank, 280 Fed. 879 (M.D. Ala., 1922), aff'd, 284 Fed. 718 (C.A. 5th, 1922). 
parent secured by a mortgage on the subsidiary's assets. The mortgage was held void as against the subsidiary's creditors. This treatment of loans as capital contributions becomes increasingly difficult as the original capital investment becomes larger. ${ }^{9}$ Cases applying the Deep Rock doctrine ${ }^{10}$ have attempted to draw the line between legitimate debt and disguised capital. One index is the extent to which continued long term borrowing from the parent occurs when the subsidiary could not have borrowed from outsiders. ${ }^{11}$

But whatever index is used for this line of cases, it is clear that the determination of adequate capital is largely a matter of hindsight. Reviewing the subsidiary's history is simplified when a plan to milk the subsidiary from the outset can be shown. In the recent case of Henderson v. Rounds and Porter Lumber Co., ${ }^{12}$ the defendant's president and another individual formed a corporation with $\$ 30,000$ and machinery adequate to produce items which were sold to the defendant at prices below market. The execution of the scheme resulted in a constant net operating loss and eventual bankruptcy. The defendant had made several secured loans to the new corporation. The court asserted that "[i]n view of the extraordinary demand for finished lumber and the enormous price at which it was selling on the market, there appears no reason why it should not have continued to be solvent, except for the action of the defendant in requiring the [new corporation] to sell the lumber to it at below cost." ${ }^{13}$ So the court found

' When there is no capital to speak of, an interesting result may ensue. Stone v. Eacho, 127 F. 2d 284 (C.A. 4th, 1942), cert. denied Eacho v. Stone, 317 U.S. 635 (1942). The total equity capital was $\$ 3.00$. Since both the parent and subsidiary were bankrupt, the court chose to lump the assets together thus treating all creditors on an equal basis.

${ }^{10}$ Taylor v. Standard Gas \& Electric Co., 306 U.S. 307 (1939). The doctrine: "Where a showing can be made that a subsidiary corporation having public preferred stockholders was inadequately capitalized from the outset and was managed substantially in the interest of its parent, rather than in its own interest, the parent will not, in a bankruptcy or reorganization proceeding affecting the subsidiary, be permitted to assert a claim as creditor, except in subordination to the claims of preferred stockholders." Israels, The Implications and Iimitations of the "Deep Rock" Doctrine, 42 Col. L. Rev. 376, 379 (1942). The inadequate capital concept aspect of the "Deep Rock" doctrine is also considered by Krotinger, The "Deep Rock" Doctrine: A Realistic Approach to Parent-Subsidiary Law, 42 Col. L. Rev. 1124 (1942).

u It is suggested by Rembar that there are three tests of inadequate capitalization at this point in the intercorporate relationship. (1) Comparisons with other corporations of similar size and nature. Contributions up to the point where the capital approximates the norm of other like businesses will be regarded as capital. (2) Advances would be viewed as capital if the subsidiary could not have borrowed from outside sources. (3) The parent's non-capital contributions should not be too great as contrasted with capital contributions. Rembar, Claims Against Affiliated Companies in Reorganization, 39 Col. L. Rev. 907, 915-16 (1939).

Israels suggests a measure of parental obligation that requires the parent to deal with the subsidiary on as favorable terms as someone else might do. "If new common stock could have been sold to others at a reasonable price, perhaps the parent should make its investment upon that basis. If new preferred was salable, perhaps the parent must take it. Perhaps only upon a showing that there was no market for common or preferred stock on reasonable terms would the parent be justified in Iending money." Israels, op. cit. supra note 10, at 391 . See also for discussions of standards, Boyum v. Johnson, 127 F. 2 d 491 (C.A. 8th, 1942), and the dissent in Barlow v. Budge, 127 F. 2 d 440 (C.A. 8th, 1942).

1299 F. Supp. 376 (W.D.Ark., 1951). ${ }^{13}$ Ibid., at 382. 
that the new corporation "was undercapitalized from the start,"14 and because of the dominion exercised over it by the defendant, the latter was held directly liable for claims against its "subsidiary." The court might also have found that the loans from the defendant were actually capital contributions and consequently available to creditors.

The problem of determining adequate capital appears to be no different from the definitional problems of Section 5 of the Uniform Fraudulent Conveyance Act, ${ }^{15}$ which declares a transfer fraudulent if the transferor is left with an unreasonably small capital. Courts deciding cases under this section have looked at the type of business involved ${ }^{16}$ and whether the business is continued after the transfer. ${ }^{17}$ The difference between the Section 5 cases and those previously discussed is that, under Section 5, only a single transaction need be analyzed. Yet the task of finding inadequate capital is frequently as restricted in scope as the determination under Section 5. The plan to sell at an unduly low price to the parent in the Rounds case; ${ }^{18}$ the management fee equivalent to net earnings in the Foard case; $;^{19}$ and the agreement to receive the product of the subsidiary free of charge except for the nominal cost of maintaining the dam in the Erickson case $^{20}$ are all examples of financial plans, the results of which may be traced without difficulty.

Thus two situations appear in which the initial capitalization of the subsidiary is clearly inadequate. One is where a mere nominal amount is paid in as equity, and the corporation is financed by cash advances and loans from the parent corporation, the parent receiving the earnings of the subsidiary. The second is where a subsidiary, which would otherwise have had adequate capital, is formed for the purpose of being milked by the parent.

While subsequent activity indicates what was necessary in the beginning, the courts are faced with an overwhelming problem. Because quantitative criteria are often artificial and unjust, courts cannot be condemned for vaguely phrasing the variables contributing to their decisions. While incorporators have no yard-

14 Ibid., at 383.

15 9A U.L.A. $\$ 5$ (1918), providing: "Every conveyance made without fair consideration when the person making it is engaged or is about to engage in a business or transaction for which the property remaining in his hands after the conveyance is an unreasonably small capital, is fraudulent as to creditors and as to other persons who become creditors during the continuance of such business or transaction without regard to his actual intent." (Emphasis added.)

16 Fidelity Trust Co. v. Union Nat'l Bank of Pittsburgh, 313 Pa. 467, 169 Atl. 209 (1933), cert. denied, 291 U.S. 680 (1933).

${ }^{17}$ McBride v. Bertsch, 58 F. 2d 797 (D.C.Mich., 1930), aff'd, 58 F. 2d 799 (C.A. 6th, 1932). See also, Kearney Plumbing Supply Co. v. Gland, 10 N.J.Eq. 723, 151 Atl. 873 (1930); Barr \& Creelman Mill \& Plumbing Supply Co. v. Zoller, 109 F. 2d 924 (C.A. 2d, 1940).

${ }^{18}$ Henderson v. Rounds \& Porter Lumber Co., 99 F.Supp. 376 (W.D. Ark., 1951).

${ }^{19}$ Joseph R. Foard Co. v. State of Maryland, 219 Fed. 827 (C.A. 4th, 1914).

${ }^{20}$ Erickson v. Minnesota \& Ontario Power Co., 134 Minn. 209, 158 N.W. 979 (1916). 
stick with which to measure their transactions, they have been put on notice that the protection of their own funds is not enough, and theirs is the responsibility of creating a financial structure which will not unduly jeopardize creditors in the event of the subsidiary's insolvency.

\section{THE TRUSTING TRUSTEE: MOSSER V. DARROW}

During his life on the bench, possibly every judge has to face a number of situations, best characterized as "painful." It is not that the law is wrong, nor even that the losing party has strong equities on his side. Rather, some poor fellow, through some form of foolish behavior has become involved in a terrible fix. He's not a bad guy - he may even be a good one. And the judge may be tempted to help extricate him from this mess. At times, it can be done; the precedent is there. At times, the circumstances are such that neither juggling judicial concepts nor realigning cases will ever ring true. In effect, this was the situation before the Court of Appeals for the Seventh Circuit in Darrow v. Mosser. ${ }^{1}$

These were the facts. In a 1935 reorganization proceeding, Judge Holly, a respected jurist, had appointed as trustee, Mr. Darrow, son of the eminent attorney but not an attorney himself. The debtor-trusts were formed in 1930 to hold the stock of several building corporations, each with bonds outstanding. Mr. Darrow retained a gentleman named Kulp and a lady named Johnsonpromoters of the subsidiaries - with the express understanding that they would be free to trade in the subsidiaries' securities. And trade they did.

Mr. Darrow had inaugurated a plan of bond retirement, and he relied on the advice of the lady named Johnson to execute this plan. Miss Johnson found herself in a not unhappy position. She knew at what prices the bondholders would sell as well as the prices that the trust would pay. Miss Johnson did not let this information go to waste. Free competition may presuppose a knowing seller and a knowing buyer, but Miss Johnson was no theoretical economist. She left the parties in their abysmal ignorance and, whenever the occasion permitted, bought from the bondholders and sold to the trust or the public at a tidy profit.

Mr. Darrow's part in this little drama was a rather perplexing one. While he believed that it would be a "dangerous practice" for him to sell securities to the trust, ${ }^{2}$ he apparently had no objection to Mr. Kulp and Miss Johnson doing so.

1184 F. 2 d 1 (C.A. 7th, 1950); Mosser v. Darrow, 341 U.S. 267 (1951).

${ }^{2}$ Transcript of Record before the Supreme Court at 341. "I thought that I had a perfect right to buy and sell securities to the trusts or anybody else if . . I I did not charge them more than they were paying for securites of the same kind at the same time.

"It was my opinion that I had a right to deal in these securities selling them either to the trusts or subsidiaries and earn a profit (I [personally] didn't do any trading out of considera- 